\title{
M oments of Emergence: Organizing by and with Undocumented and Non-Citizen People in Canada after September 11
}

\author{
Cynthia Wright
}

\begin{abstract}
Striking new campaigns across Europe, the U nited States, and Australia led by refugees, im/migrants, undocumented people, and allies challenge controls over the right to move freely across borders. Situating similar formations within Canada in transnational context, this article anatomizes the impact of September 11 on N orth American organizing. D rawing on the argument that the construction of September 11 as a national event was ideologically necessary for war abroad and criminalization of immigrants domestically, the article evaluates strategies for confronting state criminalization, detention, racialized citizenship, and "illegality." It concludes that, far from utopian, "no-border" and "undocumented" movements are fundamentally politically necessary in the current dangerous conjuncture.
\end{abstract}

\section{Résumé}

M enées par des réfugiés, des immigrants, des sanspapiers et leurs alliés, de nouvelles campagnes saisissantes ont eu lieu, à travers l'Europe, les États U nis et en Australie, pour remettre en question les contrôles sur le droit de libre circulation à travers les frontières. Cet article situe des mouvements similaires qui se sont formés au Canada dans un contexte transnational et examine de près l'impact des attentats du 11 septembre sur l'organisation des mouvements de protestation en Amérique du Nord. S'appuyant sur la thèse qu'il était idéologiquement nécessaire de présenter les attentats du 11 septembre comme un événement national afin de justifier la guerre à l'étranger et la criminalisation des réfugiés à l'intérieur du pays, cet article évalue les stratégies pour combattre la criminalisation par l'État, la détention, la citoyenneté à caractère raciste et I' « illégalité ». II conclut que, loin d'être utopiques, les mouvements en faveur de l'ouverture des frontières, ainsi que ceux formés par des « sanspapiers » ou par des gens les supportent, sont fondamentalement et politiquement nécessaires dans les circonstances dangereuses actuelles.

n his essay/manifesto, "What We Owe to the SansPapiers," French philosopher Etienne Balibar passionately argues that political contestation by undocumented immigrant people in France has made a fundamental challenge to notions of democracy, politics, civil rights, and citizenship. ${ }^{1,2}$ Indeed, in France, as elsewhere in Europe, the United States, and Australia, organizing by and with undocumented and non-citizen people has in recent years become a pressing priority; it has also begun to unsettle long-standing assumptions within political theory and practice about borders, nations, sovereignty, and the regulation of immigration. But as we look back since September 11, 2001, and observe the systematic tearing up of immigrant, refugee, and indeed civil rightsin N orth America, Australia, the UK, Europe and elsewhere - not to speak of detentions, deportations, racist killings, physical and verbal harassment, burnings of mosques and $\mathrm{H}$ indu temples, draconian anti- terrorist and domestic security bills, and much else 
- Balibar's manifesto appears wildly utopian, even as it re mains politically more necessary than ever. ${ }^{3}$ For, as M uneer Ahmad has argued in a recent article on racial violence in the aftermath of September 11, "it is exactly in moments of nationalist, nativist, and militarist excess that we might develop greater acuity not only in our critique of prevailing politics, but in the imagined alternatives." 4

It is in this context that this paper asks: what now for movements and organizations of and with undocumented and non-citizen people? I raise this question fully aware that, well before September 11, the federal government's immigration policy was moving in increasingly regressive directions. To take just one example, Canada's new Immigration Act, which originated before September 11 and which came into effect on June 30, 2002, expands powers of detention and deportation, to specify only two of its provisions. ${ }^{5}$ M oreover, the post-September 11 context has meant that policy proposals that immigrant and refugee rights groups in Canada have been opposed to for years among them the "safe third country" agreement - have been quickly brought in with comparatively little resistance. This paper offers only a very preliminary analysis of how, post-September 11, "race" and citizenship in Canada are being reconstructed in the context of calls for a security perimeter; "illegal immigrant" squads; and limitations on the mobility and other rights of immigrants, refugees, and indeed citizens of colour in the name of national security. As Sunera Thobani has recently pointed out, what we are looking at is the institutionalization of racial and national profiling. ${ }^{6}$ I can also only gesture at the forms of anti-immigration and anti-immigrant discourse that are circulating - as evidenced, to take only one example, by Daniel Stoffman's latest book, Who Gets In, which makes some very familiar anti-immigration arguments but within a post-September 11 context - and the ways in which they do or do not differ from what wehaveseen in the past. ${ }^{7}$ I ndeed, the whole question of what is new and not new about the forms of racialization and criminalization we are seeing now is an extremely important one with some clear implications for strategy and alliance-building. ${ }^{8}$

I offer this paper as a think piece about strategy and organizing, one that I hope contributes in some small way to bringing our interlocking movements - including antiracist, labour, aboriginal, immigrant rights, anti-globalization, and anti-war among others - into closer alliance. It attemptsto map somemoments of emergence- to describe, and begin to account for, some of the new directions in the immigrant and refugee rights scene in Canada: groups and actions that are a clear departure, ideologically and in social base, from many - not all - of the earlier formations and which are also linked to some of the international cam- paigns and political arguments around the demand for open borders. It is vital that activists and activist academics begin to piece together some historical and contemporary accounts of grassroots and non-institutionally-located anti-racist practice and to begin to situate them within a transnational framework. While we now have some fine scholarly accounts of the operations of racism in education, in paid work and, perhaps above all, in the arena of immigration and refugeelegislation and policy, there is relatively little work on all the campaigns and actions carried out by activists committed to anti-racist struggle in Canada - or indeed el sewhere. As the contributors to thenew collection, Rethinking Anti-Racisms, comment on the British case: "[M ]edia and political anxieties around immigration have coexisted alongside a largely unwritten history of the struggle against immigration and asylum laws."

Across Europe people are mobilizing under the banner of "No Border" and in other campaignsto contest theterms of Fortress Europe with its regime of greater movement within Europe while simultaneously subordinating people from the South. The O ctober 2002 issue of N ew Internationalist magazine is devoted to the theme "The Case for O pen Borders," and features an excerpt from the best-known English-language manifesto for an end to immigration controls, Teresa Hayter's O pen Borders. ${ }^{10}$ The choice of theme for this issue is testimony to the new confidence and growth of such international campaignsand perspectives. In England, for example, the country with "the worst record on immigration detention in Europe," and with a very low rate of refugee acceptance, much radical immigrant rights work has focused on stopping detentions and deportations.11 In France, the activism of thesans-papiersand sans-papières- autonomous formations of undocumented people who insist on speaking for themselves - has provided an important model for undocumented people and their allies everywhere. ${ }^{12}$ It has also influenced internationally known intellectuals such as Etienne Balibar, as well as M ichael $\mathrm{H}$ ardt and Antonio Negri, the authors of one the most important theoretical books to comeout of theW estern left in a generation, the hotly debated Empire. $\mathrm{H}$ ardt and Negri placean open bordersdemand at the top of a new left agenda: "A specter hauntstheworld," they write, "and it is the specter of migration." 13

Outside Europe, in Australia, we have recently seen dramatic instances of refugees breaking out of detention and of direct-action campaigns to free, and give sanctuary to, refugees warehoused outside the country's main cities and on Aboriginal territories. ${ }^{14}$ And while most discussions focus on the so-called "migrant-receiving" nations in the North, people in the global South, for example indigenous people and African-descended people in Columbia, have continued to draw attention to the ways in which they have 
been displaced by war, paramilitaries, capitalist "development," and their own states.

In the N orth A merican context, massive setbacks in immigrant rights in the U.S. since the 1990s have produced a new generation of tough and creative activists, many of whom are younger first-and second-generation immigrants of colour. Clustered in groups like the $N$ ational Network for Immigrant and Refugee Rights (N N IRR), Desis Rising Up and M oving (DRUM), and around the publication Colorlines - to name a few - they represent a total break with the politics of the U.S. melting pot and the myth of "immigrant America." ${ }^{15} \mathrm{~K}$ ey alliances between U.S. Iabour and immigrant groups, and renewed labour organizing among working-class immigrants, meant that U.S. immigrant rights and labour activists had achieved a significant victory on the eve of September 11: they moved what had been a central - if not the central - demand of the immigrant rights movement, legalization for that country's estimated six to nine million undocumented, onto the national political agenda. ${ }^{16}$ Unlike many Republicans, Bush seemed prepared to back a limited legalization plan, no doubt with a view to capturing thesizablenumber of Latino/a voters and shifting their loyalties from the Democratic to the Republican Party. ${ }^{17}$

September 11 has been a catastrophe for all such legalization and workers' rights campaigns, and indeed for antiracist and economic justice projects generally. ${ }^{18}$ In the celebration of the heroic white masculinity of firefighters, police, and (then) N ew York City mayor Rudolph Giuliani, the tremendous struggles waged largely by the city's African-American community for accountability from those same police and Guiliani were buried. ${ }^{19}$ The number of undocumented people who died in the twin towers once again revealed theextent to which glittering world cities rely on a service sector with largenumbers of both documented and undocumented immigrants. ${ }^{20}$ In an article on September 11 and New York City's Latino/a community, Arturo I gnacio Sánchez notes that some activists tried to effect a "symbolic shift" by talking about the undocumented people who died in the attack as "working heroes"; one goal of this move was to further the "struggle to secure immigrant amnesty in the U nited States and other nations." ${ }^{21}$ But such a strategic move was no match for what $\mathrm{N}$ eil Smith calls the "manufacturing of nationalism" in the aftermath of September 11: while the victims of the World Trade Center (WTC) attack came from some eighty-three countries, that story was quickly rewritten in theinterests of aU nited States bent on a permanent "war on terrorism"; for this reason, the victims had to be "nationalized." 22

TheU.S. amnesty movement had planned to establish its strength and visibility in a September 25, 2001, demonstra- tion in Washington, D.C.; it was called off. Attendance dropped off in organizations for the undocumented and public events became very difficult. M any undocumented and non-citizen people feared they were about to be rounded up. And, of course, many were. Indeed, much expanded powers of detention, and the requirement for male visitors over the age of sixteen from some twenty-five countries to register themselves by $M$ arch 21, 2003, have dramatically underlined the insecurity and precariousness of undocumented, non-citizen, and refugee lives..$^{23} \mathrm{M}$ eanwhile, the ongoing militarization of the M exico/U .S. border, not to speak of the presence of vigilante whiteranchers who murder suspected "illegals," mean that migrants continue to risk their freedom and their lives crossing the border from M exico into the United States. ${ }^{24}$ While immigrant rights activists continue to organize around it, the demand for legalization was almost forced off the public agenda in the United States, and may yet be sacrificed altogether because M exico has refused enthusiastically to back the United States' war on I raq. ${ }^{25}$ Instead, "illegal immigrants" and non-U.S. citizens are being offered a visa if they provide tips about "terrorists" - even if no criminal conviction results from that information. ${ }^{26}$ Recently, however, Democratic representative Luis Gutierrez has reintroduced a bill that would provide for a rolling amnesty for undocumented people. ${ }^{27}$

Here in Canada, where organizations by and for the undocumented and their allies have been weak or non-existent until relatively recently, such legalization or amnesty campaigns have few precise parallels and radical immigrant rights work has relatively little public or media profile.. ${ }^{28} \mathrm{At}$ one level, this is a question of scale; there are millions of undocumented people in the U.S., while the figures for Canada in journalistic accounts range widely from 20,000 to $200,000 .{ }^{29}$ But it is also, crucially, a question of political context and contest: a series of highly charged cases surrounding "illegals," as well as the mass campaign to stop Proposition 187, have contributed to a fierce public and media debate in theU.S. about immigration and opened up space for advocating the rights of undocumented people. M ost importantly, undocumented people have also begun to come forward and speak on their own behalf - crucial in the North American media context where literally putting a "face" to a political issue is key to how it gets framed. ${ }^{30}$

An overview of groups, campaigns, and activities directed at the rights of undocumented and non-citizen people living in Canada reveals that, unsurprisingly, most appear to be clustered in V ancouver, Toronto, and M ontreal - the cities with the largest immigrant populations and with important and ongoing histories of anti-racist/immigrant rights organizing. In Vancouver, the O pen the Borders! 
group recently organized an international activist/academic conference on displacement, borders, and immigration with a view to building a movement for no borders. ${ }^{31}$ Not long after, and in a striking illustration of what is at stake for non-citizen people, an I ranian woman scheduled for deportation broke free at the Vancouver airport and made a dramatic bid for escape - only to be apprehended and deported not long after. ${ }^{32}$ M eanwhile, hundreds of other non-status people in that city's Chinese and I ranian communities have begun to organize.

In Toronto, STATUS Coalition formed in May 2001, when a group of undocumented Latino men in the construction sector approached a Toronto lawyer about their situation; the lawyer in turn put out a call to agencies serving immigrants to see who might be interested in initiating a campaign for legalization as part of the lead-up to the new immigration bill. The Ontario Coalition Against Poverty, also based in Toronto, has expanded its powerful and galvanizing direct action approach to housing and poverty issues to include immigration casework, including undocumented people and refugees. ${ }^{33}$ Other groups are leading a host of related campaigns including exposing immigration detentions at Toronto's Celebrity Inn; working with migrant agricultural workers on temporary work permits; and developing among Church-affiliated peoplea sanctuary movement for refugees now that the "safe third country agreement" is effectively a reality. Still others, in both Toronto and Ottawa, are contesting the terms of the national security state by challenging the use of secret trials and security certificates, while activists in smaller Ontario cities such as Guel ph have resisted plans to build detention centres in their communities.

Montreal is home to the country's most visible and well-known campaign for legalization, one that provides important testimony to what may be accomplished even in unfavourable conditions when non-status people self-organize, mobilize both women and men, insist on speaking for themselves, and build a campaign with committed allies. $^{34}$ In the spring of 2002, the federal government re moved Algeria from the short list of countries to which Canada does not deport; for Q uebec's failed Algerian refugee claimants, more than one thousand in number, it was deeply disturbing news. They were to be deported to a country locked in a decade-long and deadly violent conflict - an Algeria so dangerous that the Canadian government to this day warns its citizens to avoid tourist visits there. In response, the Comité d'action des sans-statut algériens (CASSA) advanced three basic demands: (1) stop the de portations; (2) return Algeria to the moratorium list; and (3) regularize non-status Algerians. By the fall of 2002, the last demand had expanded to include a call for the legaliza- tion of all non-status people living in Canada, a move that recognized theslow but growing support for such a demand in other parts of the country, particularly Toronto.

Working with the allied group, No One Is Illegal, and with the support of numerous individuals and labour, faith, and women's organizations, the Comité has put together a well-organized campaign of activities, one which has included holding press conferences and rallies, making unscheduled visits to immigration offices, seeking sanctuary in a church, and giving public talks in Montreal and Toronto - all of which have garnered a significant amount of press coverage in both French and English. M uch of the coverage is sympathetic to the claims of the non-status Algerians - particularly striking given that the campaign began not long after the events of September 11 and M ontreal's Algerian community had been targeted as home to terrorist plots. CASSA members and their allies have re peatedly drawn attention both to dangerous political conditions within Algeria and also to Canada's complicity in constructing that country as "safe" for North American business interests - and for sending people back "home." Indeed, as more than one analyst has argued, the two go together in the current neo-liberal order: within the EU, for example, "repatriation agreements" are becoming "an explicit condition of new trade deals: We'll take your products, the Euros say to South America and Africa, as long as we can send your people back." ${ }^{35}$

Certainly, the French-language ability of many Algerians has been a major asset in enabling the community to speak directly to Quebec's francophone media and immigration officials at all levels; in this regard, they have an advantage not enjoyed by those non-status people who are not fluent in English or French, and who may also lack effective allies who can act as interpreters. Secondly, CASSA members have insisted on their claims as refugees, and indeed such a strategy is important in a context in which claims for the right to stay of non-status immigrants can often, by comparison, be more difficult to argue successfully. Bob Sutcliffe put it succinctly in a recent article: "Political migrants are in principle characterised as helpless victims who deserve help. Economic migrants are increasingly portrayed as selfish, grasping people, only out to get moremoney. The distinction has therefore been made into a moral one between good and bad migrants." ${ }^{36}$ Yet it must also be acknowledged that the category of "political migrant" or "refugee" is itself increasingly under attack in neo-liberal context ${ }^{37}$ and thefigure of the "bogus refugee" is ubiquitous in popular immigration debates; indeed, the resignification of all the terms we have been used to working with in immigrant and refugee rights campaigns suggests that the strategic implications of working within and against state 
categories such as "immigrant" and "refugee," among others, will need to become the focus of greater scrutiny and reflection by activists.

These diverse formations and campaigns in Vancouver, Toronto, and $M$ ontreal are exciting and many are breaking new ground; it would bea big mistake, however, to assume that they necessarily share the same origins, base, or political outlook and strategy. However, some preliminary observations may be made about some of the actors involved in such campaigns. It is clear that a "no borders/no one is illegal" politic is capturing the political imagination of many anti-globalization and anti-war activists, many of whom are younger people of colour with immigrant or refugee backgrounds and who want a much stronger antiracist analysis integrated throughout these movements. Clearly, this is reflective of some of the international conversations in the anti-globalization movement. Radical anti-deportation, anti-detention, and no-border campaigns in Europe and, more recently, Australia are one obvious major influence, but conditions in Canada are also radicalizing many. These conditions include increasing detentions, deportations, racial and national profiling, surveillance, and the inhumane treatment afforded to failed refugee claimants or to those, such as the Asian migrants of a few years ago, who arrive at the country's borders and shores.

Tired of the racism, and not inclined to take up old defensive arguments about "the contributions of immigrants to Canada," or indeed about the basic fairness and soundness of the immigration system in the face of attacks on it from the right, younger activists are elaborating a different political language. Rejecting the binaries of "good immigrant"/"bad immigrant," "legal"/"illegal," and "political refugee"/"economic migrant," it is a politics that speaks both to the causes of displacement globally, and to the right of people to move across borders freely with full labour, social, and citizenship rights. It is a politics that, for some, may also be explicitly linked to an anti-national and anticolonial perspective, and one which attends to the need to bring together Aboriginal rights and im/migrant rights through a common critique of displacement, dispossession, and the power of nation-states to construct regimes of racialized citizenship. ${ }^{38}$

It is important not to overestimate the strength of these autonomous groups; many are relatively new and somewhat fragile, and all are under-resourced. Whether led by those most directly affected (CASSA, for example) or by their allies, such organizations typically have very low or no budget and, consequently, no staff. Typical of grassroots organizations, thework is often highly labour-intensiveand unpaid, and involves a willingness to confront bureaucra- cies and officials head-on. Such an approach differs distinctly from that of more long-standing refugee rights groups or agencies serving immigrants - many of which have long emphasized strategies based on lobbying and changes to the law, and many of which may bereluctant to publicly defend those whom the State constructs as "illegals," much less advocate an "open-the-borders" position. Unlike in the U nited States, wherelegalization for that country's millions of undocumented remains (even after September 11) the central demand of the immigrant rights movement, some more established immigrant/refugee rights groups in Canada have sometimes viewed the call for legal ization (never mind opening the borders) with what could bedescribed as a lack of enthusiasm. Service agencies facing funding cuts, restructuring, and a conservative political climate may be unwilling - or too burdened by existing demands - to implicate themselves in high-profile campaigns.

At their best, allied organizations may embody what is best about a grassroots organizing approach: working directly with those most affected - whether they be detained, undocumented, migrant workers, refugees, deportees - in order to make concrete change in everyday lives and, in the process, democratizing knowledge and analysis about the law and much else. The emphasis is on collective decisionmaking, democratic involvement of affected and allied people, and building solidarity. At other moments, the immense amount of work involved - especially in defending individual cases - may mean that little energy is left over for broader community organizing, much less sustaining longterm campaigns around immigration and borders. Yet, as activists acknowledge, in the absence of national co-ordination - and, ultimately, transnational alliances of all kinds - gains will be limited. Hard-won interim or partial successes in individual immigration cases or, more rarely, an affected community (such as the Algerians) are simply not translated into long-term transformations.

$\mathrm{N}$ ational co-ordination of work in Canada is still, for the most part, in formation, although there was an important "No One Is I llegal" demonstration in Ottawa in June 2002 as part of the G8 protests. M ore recently, a February 2003 conferencein $\mathrm{M}$ ontreal brought together activists from that city, Vancouver, Toronto, O ttawa, Guel ph, and other communities with a view to developing a co-ordinated, long-term campaign with a core set of demands, a basis of unity, a plan of action, and an organizational structure flexible enough to accommodate existing local formations/campaigns while still able to sustain effective, ongoing work in a variety of centres.

So, what now? On both sides of the Canada/U.S. border, immigrant rights movements and organizations have been regrouping, rebuilding and rethinking strategy since September 11 . In the Canadian case, as wehave seen, significant 
new organizing has in fact emerged since September 11 in spite of - and indeed because of - conditions that by the day become more deeply unfavourable. In what follows, I want to comment on some of the broad strategic dilemmas currently facing activists; such an analysis ultimately needs to consider how to bring together political questions that werealivewell prior to September 11 (for example, struggles around Aboriginal self-determination or thedeportation of Afro-Caribbean people $\mathrm{e}^{39}$ ) with the newer challenges and racialization processes/targets we currently face. My focus here will be on Canada and the U nited States. While many activists have been most influenced by European and Australian no border/no detention organizing, the fact is that Canada's geographical and political/economic relationship to the American empire needs to be the focus of some serious analysis, reflection, and cross-border action. It is in this context that the lack of ongoing co-ordinated work between activists on either side of the Canada/U.S. border emerges as a very serious weakness. $M$ y analysis will necessarily remain partial and preliminary given the sheer number of changes that have occurred since September 11 , as well as their far-reaching implications, not all of which are clear. Moreover, the so-called "war on terrorism" which many have argued is in essence "a war for U.S. globalism" - has created a very volatile political context which continues to shift quite rapidly. ${ }^{40}$

What is abundantly clear is that, as one U.S.-based activist commented, "The 'homeland defense' agenda and the war are two parts of the same thing." 41 In his provocative essay on the "manufacturing of nationalism," Neil Smith suggests a way to elucidate this relationship by asking, "A global event and yet utterly local: how did September 11 become a national tragedy?" ${ }^{42} \mathrm{H}$ is essay details some of those national practices in the immediate aftermath of September 11, all of which were reinforced - and yet simultaneously revealed for analysis - by anxious media silences, gaps, and outright censorship. One move, as we have seen, was to "nationalize the victims" as Americans ("Why do they hate us so much?"); but others included immediately shutting down the borders and airports; defining terrorism to exclude "Americans"; and closing the stock exchange for several days, thus "revealing in stark outline the very real fusion (and confusion) of an ideological Americanism with the interests of global capitalism." 43 If national victims had to be identified, so too did national enemies - both abroad (Afghanistan, then I raq) and, crucially, at home. Racial and national profiling - and much else - has been the result. The ideological and practical work of constructing the WTC attack for American nationalism was necessary in order to lay the groundwork for the violence and war that followed since "nationalism is the discourse of war under modern capitalism, in which the national state has cornered a monopoly on violence. In this case it is a national monopoly over violence asserted at the global scale."44

O ne clear dilemma is that, despite the emergence of an international anti-war movement unprecedented in human history, its N orth American wing simply does not (yet) have the strength to turn back the discourses/practices of homeland and national security. But without a highly organized and broad anti-war movement which clearly addresses both the war and domestic racism, the rights of immigrants of whatever status, as well as of citizen people of colour, will continue to erodedramatically, for "national security" is an extremely powerful and mobilediscourse. As Kinsman, Buse, and Steedman state, "Under its regime, those who are defined as 'security threats' can be excluded from regular human and citizenship rights." 45 The detentions, semi-secret trials, and abuses of all sorts currently taking place on both sides of the border (and beyond, as in Guantanamo) provide ample evidence. General calls at anti-war rallies and forums to defend civil liberties, including those of immigrants, refugees, and racialized communities (particularly M uslims, South Asians, and Arabs) are certainly important at one level; they arealso wholly inadequate given the dimensions of the racist nationalism that we are dealing with here. ${ }^{46}$

A broad key strategic point, then, is that we must understand immigration and anti-racist politics as deeply bound up with anti-war politics, and vice versa. In Canada, weare seeing some renewed public debate about U.S. imperial power as we are pulled ever deeper into the American empire. Deeply important as this opening has been, the force of such critiques has often been blunted by perspectives that centre the "Ioss of Canadian sovereignty" as the key issue; one challenge, then, is to develop a very different kind of analysis, one that asks the questions from thestandpoint of immigrants, refugees, undocumented people, and racialized communities. ${ }^{47}$ This means, among many things, challenging directly the discourses of nationalism and "national security." We have to continually ask: whose security? whose nation? In Canada, this poses a number of particular difficulties. For a start, the national security apparatus in Canada has, historically, been more secretive in fact than the American one. Second, despite important books such as the accessible academic collection Whose $\mathrm{N}$ ational Security? (on the history of state surveillance and itstargets) and journalist Zuhair Kashmeri'sT he Gulf W ithin ${ }^{48}$ (on the harassment of Arabs and Muslims in Canada during the Gulf War), it is striking how few people seem to have a working knowledge of even the recent history of the security apparatus in Canada; one consequence of this has been that the iconic memory that was frequently invoked 
in debates and forums about civil liberties and "national security" in the months after September 11 was that of $\mathrm{M} \mathrm{cC}$ arthyism and Cold War United States. ${ }^{49}$ Yet, without that historical memory and analysis, we will not be able to identify some of the continuities (as well as discontinuities) with past national security practices; for example, in the wake of September 11, agencies and services for immigrants were to obtain security clearances for their employees as an "anti-terrorism" measure, a move that clearly recalls security and surveillance campai gns directed against immigrant communities in Canada during the post-World War II period. ${ }^{50}$

Challenging the terms of "national security" also means resisting any move to re frame existing immigration campaigns within that discursive framework. In the United States, for example, some have sought to present the demand for legalization of undocumented peopleas a security measure. As an activist with the Border $\mathrm{N}$ etwork for $\mathrm{Hu}$ man Rights commented, "I have fears that some people, including our companeros in unions, believe the only way to get legalization is to define it as an issue of national security, as a process for identifying everyone." ${ }^{51}$ The undocumented movement in the U.S. gained significant ground by forming a key alliance with the labour movement; therefore, the AFL-CIO's reaffirmation in December 2001 of support for legalizing undocumented workers was very important. But the AFL-CIO's official position in support of the war on Afghanistan, and its acceptance of limitations on the rights of non-citizen workers, was a major, though not surprising, setback. ${ }^{52}$ (U.S. tradeunion opposition to the more recent war on I raq, it should benoted here, is a welcome development. $)^{53} \mathrm{On}$ this side of the border, and to its credit, the official labour movement in Canada has been far less enthusiastic about A merican-led wars, and a post-September 11 statement by the Canadian Labour Congress (CLC) warns of the abuses of "national security" arguments for trade unionists. M oreover, CLC vice-president H assan Yusef spoke publicly in favour of legalization of the undocumented at a forum organized by STATUS in Toronto in December $2001 .{ }^{54}$ But new challenges are constantly appearing. The recent finding by Canada's AuditorGeneral, Sheila Fraser, that some thirty-six thousand "illegals" have not been deported or accounted for is being framed as a security issueby the media. ${ }^{55}$ The various groups calling for legalization on this side of the border have for the most part resisted the move to pose status for undocumented people as a national security question. At the same time, the campaign for legalization - as in the U nited States - has been nowhere near strong enough to form a counterweight to border panics about "illegals" and security.
While campaigns for legalization of undocumented people in both Canada and the United States continue to be deeply necessary, we also have to confront the fact that, as Jane Bai and Eric Tang have argued for the U .S. case, "The 'war at home' has shifted the dividing line from documented vs. undocumented to citizen vs. non-citizen." ${ }^{56}$ The post-September 11 context makes much starker what has always been a reality: merely being "legal" is never enough in the absence of full social, labour, and political rights. Being "legal" is little use if you can beeasily detained and/or deported. Recent changes in U.S. legislation mean that the rights of non-citizens have once again been dramatically reduced, and Canada's new Immigration Act makes the deportation of non-citizens easier. Canadian Prime M inister Jean Chretien further underlined these realities by his stunning refusal to defend therights of permanent residents in Canada facing racial and national profiling in the U nited States: "If they do not have a Canadian passport, it's no longer my problem... Let them become Canadian citizens, and we will protect them." ${ }^{157}$ But the fact is, as Bai and Tang also acknowledge, citizen rights of people of colour are always precarious; the aftermath of September 11 has dramatically served to highlight this once again. The Canadian state appears unwilling to vigorously protect the rights of Canadian citizens apprehended, detained, or kidnapped by U.S. authorities; figures such as Shakir Boloch (detained in the U.S. for months) ${ }^{58}$ or $M$ aher Arar (still detained in Syria) come to mind. Challenging the terms of racialized citizenship must, therefore, be added to the long list of political priorities for the current context; one immediate implication is that we need to challenge any attempt to further widen distinctions between citizen and non-citizen, and also distinctions within those categories.

A key part of theU.S. "homeland defense" agenda - with its racial and national profiling, arbitrary detentions, de struction of civil rights, and much else-is bringing Canada and Mexico into it through the creation of a so-called "security perimeter." N aomi Klein has commented recently that the U.S. is constrained both to lock down its northern and southern borders and to demonstrate to business interests that delays at the border will not cost them money currently a serious problem. The way around this apparent conflict in imperatives is to harmonize borders and make Fortress NAFTA: "H ow do you have air-tight borders and still maintain access to cheap labor? How do you expand for trade, and still pander to the anti-immigrant vote? $\mathrm{H}$ ow do you stay open to business, and stay closed to people? Easy: first, you expand the perimeter. Then you lock down." ${ }^{59}$ The U.S. has exerted serious pressure on both "Canada and M exico to harmonize their refugee, immigration and visa laws with US policies." ${ }^{60}$ The ongoing and 
active ideological construction since September 11 of Canada's border as porousand as a conduit for "terrorists" to cross into the U nited States must be understood in this light. ${ }^{61}$

One of many ways that the terms of the security perimeter might be challenged is from the standpoint of policing, prisons, and detention. Ontario's current M inister of Public Safety and Security is highly committed to a detention system along the lines of the now-notorious Australian one. ${ }^{62}$ It is also clear that onekey component of the practical implementation of the security perimeter is the greater integration of policing across borders, as well as within each country, as Toronto's recent Great Lakes Security Summit makes clear. U.S.-based activists Bai and Tang, in an analysis of "The War at Home," argue that what can potentially provide a unifying focus for U.S. anti-racist and immigration rights activists post-September 11 is renewed organizing directed at policing and "the prison industrial complex" because they are now being dramatically reorganized and expanded to target a whole new range of non-citizen and undocumented people in addition to the African-Americans and aboriginal people who have been in the past, and who continue to be, among those most likely to be racially profiled and incarcerated. ${ }^{63}$ Their analysis is aimed at linking contemporary immigrant rights agendas with the historic struggles led by African-American and Aboriginal people- struggles that are often articulated separately in the U.S. context. While policing, prison, and detention struggles in Canada have differed in some important ways from their U.S. counterparts, as have the respective social movements, such a political focus could be potentially unifying of aboriginal, anti-racist, and immigrant/refugee rights groups in Canada as well. In short, as Bai and Tang bluntly put it: "The immigrant rights movement can ill-afford to view state violence as peripheral to its long-term core issue, legalization of the undocumented." ${ }^{64}$

In recent years, we have seen the development of striking new campaigns across Europe, the U nited States, and Australia as refugees, immigrants, migrant workers, undocumented people, and their allies have sought to challenge controls over the right of people to move freely within and across borders. France and the U nited States offer particularly striking examples of undocumented people as political agents, and in both of these settings the struggles of nonstatus people have captured the imagination of numerous allies, artists, and political theorists. Campaigns emerging in Canada - among them renewed calls for the legalization of undocumented people; self-organizing by non-status people themselves; anti-deportation/anti-detention work, defense and sanctuary - have clearly been influenced by local developments, but also by transnational conversations within the no-border and anti-globalization move- ments and by the campaigns for legalization south of the border.

In the United States, where millions of undocumented people live without status and full labour rights, immigrant rights campaigns have focused on the call for amnesty and have clearly demonstrated what American political theorist Bonnie Honig describes as "the potential power of the undocumented as political actors, labor organizers, and community activists." ${ }^{65} \mathrm{H}$ er work reminds us that, while anti-immigrant legislation, policy, and practice may appear to be about keeping (some) people out, the dependence of the U.S. economy on their labour suggests that the goal has been not so much stopping cross-border migration but criminalization - and making the costs of political agency and visibility too high to be sustained by immigrant communities. ${ }^{66}$ But mass organizing by immigrant communities and their allies continued in spite of this ongoing criminalization and, after years of setbacks, it was finally looking like it might pay off as legalization began to seem like a realistic political possibility.

However, the events of September 11 - immediately appropriated for a U.S. nationalism bent on war - haveled to a "homeland security" agenda that has exacted a terrible toll on all projects for racial, economic, and gender justice in the United States and will have lasting effects on the political mobilization of immigrant and racialized communities within the United States and also Canada for many years to come. ${ }^{67}$ The so-called "security perimeter" is the extension of many aspects of the "homeland security" agenda to Canada and to M exico; on the northern border front, this has been accompanied by numerous border panics about "terrorists" and "illegals," as well as calls for new powers of detention and much else. It has al so dramatically underlined the need to internationalize our often locally and nationally bound immigration struggles.

Yet, there are some signs of hope: namely, an unprecedented anti-war movement, building in part on prior antiglobalization activism as well as on mobilization by people with origins in the regions most affected by war in the Middle East and Central Asia. Yet, on both sides of the Canada/U.S. border, there has been a failure to fully connect the anti-war movement with a clear and direct challenge to surveillance, detention, racialized citizenship, and national security logics. One way to do that, I have suggested, is to begin to examine current border panics and nationalisms from the stand point of immigrants, refugees, and the undocumented. Legalization and other immigrant rights campaigns, for their part, now face more starkly than ever the problem of state violence and criminalization, and will need to reshape alliances and strategies accordingly. The stakes are now vastly higher than when Balibar wrote 
his well-known manifesto in support of the French sanspapiers. But that fact changes nothing about his analysis. Of the undocumented, Balibar writes that they "have shown that their illegality has not been reformed by the state but rather created by it. They have shown that such a production of illegality, destined for political manipulation, could not be accomplished without constant attacks on civil rights... nor without constant compromises with neo-fascism and the men who promote it." ${ }^{18}$ It is in this context that renewed challenges to borders, nationalisms, and state categories must be understood - not as unrealizable and utopian - but as democratic political projects directed at dismantling "global apartheid." ${ }^{69}$

\section{Notes}

1. I would like to thank Michelle Lowry and especially Peter $N$ yers for encouraging me to contribute to this special issue. I also want very much to thank $N$ andita Sharma who has shared her work and passionateengagement with theseissues with me in many late-night conversations. Without the political commitment of many immigrant rights activists and groups with whom I have been deeply fortunate to work in solidarity, this article could not have been written - although it should not be assumed that they necessarily share the opinions expressed here. This articleis a longer and much more developed version of talksI presented at two conferences: Open theBorders; and Sociology for Changing the World: Political Activist Ethnography. I thank the organizers of these conferences, as well as my audiences, for their support and discussion. Finally, thanks to $\mathrm{M}$ ary-Jo N adeau for practical assistance of all varieties.

2. EtienneBalibar, "What We Owe to the Sans-Papiers," in Social Insecurity, ed. Len Guenther and Cornelius H eesters(Toronto: Anansi, 2000).

3. For an account of the impact of the "war on terrorism" on civil libertiesin theU.S., seeM ichael Ratner, "M aking U sLessFree: War on Terrorism or War on Liberty?" in I mplicating Empire: Globalization and Resistance in the $21^{\text {st }}$ Century W orld Order, eds. Stanley Aronowitz and Heather Gautney (New York: Basic Books, 2003) and the dossier on "Arabs, M uslims and Race in America" in M iddleEast Report 224 (2002). For Canada, see Ronald J. Daniels, Patrick M acklem, and Kent Roach, eds., The Security of Freedom: Essays on Canada's Anti-Terrorism Bill (Toronto: University of Toronto Press, 2001).

4. Muneer Ahmad, "Homeland Insecurities: Racial Violence the Day after September 11," Social Text 72 (2002): 101.

5. Kirk Makin, "Automatic Deportation Law Hinders Justice, Experts Say," Globe and M ail (Toronto), 30 September 2002.

6. Sunera Thobani developed this analysis in a presentation at theconference on Racism and $\mathrm{N}$ ational Consciousnessheld at N ew College, U niversity of Toronto, on 26 October 2002. See also her "Saving the West: Reflections on Gender, Race and the War on Terrorism," Fireweed 80 (2003): 9-34.

7. Daniel Stoffman, Who Gets In: What's Wrong with Canada's Immigration Program and $\mathrm{H}$ ow to Fix It (Toronto: M acfarlane
Walter and Ross, 2002). For a critique of earlier work on immigration by Stoffman, see Cynthia W right, "N owhere at Home: Gender, Raceand the M aking of Anti-Immigrant Dis course in Canada," Atlantis 24 (2000): 38-48.

8. For some beginning reflections on this, see Ahmad.

9. Floya Anthias and Cathie Lloyd, eds., RethinkingAnti-Racisms: From Theory to Practice (London: Routledge, 2002), 11; Ali Rattansi and Sallie Westwood, eds., Racism, M odernity and I dentity on the Western Front (Cambridge, UK: Polity Press, 1994).

10. "The Casefor O pen Borders," special issue of N ew Internationalist 350 (2002); Teresa Hayter, O pen Borders (London: Pluto Press, 2000). For a review of Hayter's book and others on the same theme, see Jacob Stevens, "Barring the Doors," N ew L eft Review 12 (2001): 152-59.

11. Bill MacKeith, "Contribution to Vancouver Open Borders Conference, M arch 2002," (unpublished paper in the author's possession), 3. M acK eith is a member of Barbed Wire Britain Network to End Detention of Refugees and Migrants (UK). For more on Britain, see H ayter and also Anthias and Lloyd.

12. There are now a number of accounts of the sans-papiers. See, for example, JoannaSimeant, La Causedessans papiers (Paris: Presse de Sciences po, 1998). The website <www.gisti.org> offers current information on campaigns within France, including that of the sans-papiers.

13. M ichael $\mathrm{H}$ ardt and Antonio N egri, Empire(Cambridge, $M$ ass.: Harvard University Press, 2000), 213.

14. For a sense of the campaigns around refugees and detention currently being waged, consult Desert Storm online: $<w w w$.antimedia.net/desertstorm $>$. On the politics of race and nation in Australia, see Ghassan Hage, White Nation: Fantasies of White Supremacy in a M ulticultural Nation ( $N$ ew York: Routledge, 2000).

15. On the myth of "immigrant America," see Bonnie Honig, Democracy and theForeigner (Princeton: Princeton U niversity Press, 2001). On immigrant rights activism, see GraceChang, DisposableD omestics: I mmigrant W omen W orkersin the Global Economy (Cambridge, M ass.: South End Press, 2000); Sasha Khokha, "Paper Chase," Colorlines 4 (2001): 26-29; Lisa SunHeePark, "N avigating theAnti-Immigrant Wave:TheKorean Women's Hotline and the Politics of Community," in Community Acitivism and Feminist Politics: Organizing across Race, Class, and Gender, ed. N ancy N aples (New York: Routledge, 1998); Amitava Kumar, Passport Photos (Berkeley: U niversity of California Press, 2000); Lisa Lowe, Immigrant Acts: On Asian American Cultural Politics (Durham: Duke University Press, 1996); Elizabeth M artinez, De Colores M eans All of U s: Latina Views for a M ulti-Colored Century (Cambridge: South End, 1998); "The Immigration Backlash" special issue of NACLA Reports 29 (1995).

16. David Bacon, "Which SideAre You On?" Colorlines 4 (2001): 30-32.

17. Michele Waslin, "Immigration Policy in Flux," NACLA Re ports 35 (2001): 34-38. 
18. Chisun Lee, "The Other Disaster: Tough Times Ahead Bode W orst for City's Poorest," Village Voice, 16 October 2001.

19. Manning Marable, "9/11: Racism in a Time of Terror," in Aronowitz and Gautney, 7. I am also grateful to New York activist Humberto Brown for his analysis on these themes (personal communication).

20. Saskia Sassen, "Analytic Borderlands: Race, Gender and Representation in theN ew City," in Race, Identity, and Citizenship, ed. Rodolfo Torres, LouisF. M irón, and J onathan Xavier Inda (Oxford, UK: Blackwell, 1999).

21. Arturo Ignacio Sánchez, "From Jackson Heights to Nuestra America: 9/11 and Latino N ew York," in After theW orld Trade Center: Rethinking New York City, ed. Michael Sorkin and Sharon Zukin (N ew York: Routledge, 2002), 149.

22. Neil Smith, "Scales of Terror: The M anufacturing of Nationalism and the War for U.S. Globalism," in Sorkin and Zukin, 98.

23. Prithi Y elaja, "Seeking Shelter from the U.S. storm," Toronto Star, $9 \mathrm{M}$ arch 2003. For a timeline of some of the policies and changes affecting immigrants, see "Under Homeland Security," Colorlines 6 (2003): 18-19. For accounts of organizing in response, see Liza Featherstone, "Fighting the War at Home," The Nation, 1 A pril 2002; Chisun Lee, "D efending America's Least Wanted," Village Voice, 15-21 January 2003; Ahmad, 111-12.

24. Mike Davis, "Magical Urbanism: Latinos Reinvent the Big City," N ew Left Review 234 [old series] (1999): 3-43. See also the documentary $\mathrm{N}$ ew W orld Border, directed by Casey Peck and Jose Pal ofox (1999) and available from the $\mathrm{N}$ ational $\mathrm{N}$ etwork for Immigrant and Refugee Rights, online: <www. nnirr.org>.

25. Paul Knox, "Bin Laden Blues with a Latin Beat," Globe and Mail (Toronto), 28 N ovember 2001.

26. "Trading Citizenship for a Terrorism Tip [editorial]," Globe and $M$ ail (Toronto), 3 December 2001.

27. For discussion, see the online newsletter of the National $N$ etwork for I mmigrant and Refugee Rights at <www.nnirr. org>. Thanks to NanditaSharma for drawing my attention to recent legislative developments in the U.S.

28. Veteran immigrant rights activists will know the prior work on non-status people. See, for example, the conference kit from "Living Without Status: Human Rights Underground," held in Toronto, 2-3 M arch 1998 (in author's possession). On the history of prior legalization schemes in Canada, see Freda H awkins, Critical Years in Immigration: Canada and Australia Compared, $2^{\text {nd }}$ ed. (M ontreal: M cGill-Queens, 1991). For a rare account by a non-status person from the Caribbean, see H aile Telatra Edoney, Cry of the Illegal Immigrant (n.d. but c.1970s; photocopy in author's possession). The story of the "paper sons" within the Chinese-Canadian community can also be set within the context of a long history of challenges to the State production of illegality. For the story of one "paper son" who died without citizenship after almost fifty years in Canada, see Nicholas Keung, "Final dignity for a homeless man," Toronto Star, 11 M arch 2002.
29. Valerie Lawton and Allan Thompson, "Still in Canada? No OneKnows,"

Toronto Star, 7 October 2001.

30. Lauren Berlant, "The Face of America and the State of Emergency," in Disciplinarity and Dissent in Cultural Studies, ed. Cary Nelson and Dilip Parameshwar Gaonkar (New York: Routledge, 1996).

31. The conference "Unsettling Imagi(nations): Towards Re-configuring B/orders" washeld in Vancouver, 22-24 M arch 2002. For discussion, seeCynthia W right, "O pen theBorders! Interview with Nandita Sharma," N ew Socialist 37 (2002): 5-9. For more on O pen the Borders, see their website at <www.opentheborders.org>.

32. Rod M ickleburgh, "Woman's Escape an Embarrassment for Immigration," Globe and M ail (Toronto), 23 January 2003.

33. Michele Landsberg, "Officials H ound Woman Fighting Deportation," Toronto Star, 13 A pril 2002.

34. For an excellent account of the campaign of the non-status Algeriansin M ontreal, seethediscussion in Peter Nyers, "Abject Cosmopolitanism: The Politics of Protection in the AntiDeportation Movement" (unpublished paper, 2003, in the author's possession). I thank Peter for generously sharing his work with me. For more on the campaign, see the bilingual kit, "Press Clippings September-December 2002," available from the Comité d'action des sans-statut algériens. See also their website at <www.tao.ca/ sans-statut>.

35. Naomi Klein, "The Rise of the Fortress Continent," The Nation, 3 February 2003; available online: <www.thenation.com> (date accessed: 16 J anuary 2003); $N$ yers, 33.

36. Bob Sutcliffe, "Migration Citizenship: Why Can Birds, Whales, Butterflies and Ants Cross International Frontiers More Easily than Cows, Dogs and Human Beings?" in M igration and M obility: The European Context, ed. Subrata Ghatak and AnneShowstack Sassoon (N ew York: Palgrave, 2001), 76.

37. William Pittz, "No Safe Haven," Colorlines 5 (2002): 21-23; Thomas Wagner, "Blair Feels Heat over Get-Tough Plan for Refugees," Toronto Star, 28 January 2003. For some historical considerations on "refugee," see Saskia Sassen, Guests and Aliens (New York: N ew Press, 1999).

38. For more on these themes, see Wright, "Open the Borders! Interview with $\mathrm{N}$ anditaSharma." For moreon theintersection (and divergences) between aboriginal rights and immigrant rights, seeLeslieM armon Silko, "TheBorder Patrol State," The Nation, 17 October 1994, and the reflections on aboriginal sovereignty and diaspora peoples in James Clifford, Routes: Travel and Translation in the Late Twentieth Century (Cambridge, M ass.: H arvard University Press, 1997).

39. Simone Browne, "'Of Passport Babies' and 'Border Control': The Case of $M$ avis Baker $v$. M inister of Citizenship and Immigration," Atlantis 26 (2002): 97-108.

40. There is, of course, a large and growing literature in this area. See, for example, Tariq Ali, The Clash of Fundamentalisms: Crusades, Jihadsand M odernity (London: Verso, 2003) and the author's interview with him, Cynthia Wright, "The Wars: Tariq Ali on Building Anti-war Movements, Debating the 
'Civilization M ongers' and Narrating the History of Islam," FUSE 25 (2002): 28-40; Sunera Thobani, "War Frenzy," Atlantis 27 (2002): 5-11; Sedef Arat-Koc, "Imperial Wars or Benevolent Interventions? Reflections on 'Global Feminism' Post September 11 ${ }^{\text {th }}$," Atlantis 26 (2002): 53-65; Aronowitz and Gautney; Sorkin and Zukin; Susan H awthorne and Bronwyn Winter, eds., September 11, 2001: Feminist Perspectives (North M elbourne, Australia: Spinifex, 2002); "911- A Public Emergency?" special issue of Social Text 72 (2002). For a fascinating historical account, see M elani M cAlister, Epic Encounters: Culture, M edia, and U.S. Interests in the M iddle East, 1945-2000 (Berkeley: University of California Press, 2001).

41. Julie Quiroz-M artinez, "For War and Workers?" Colorlines 5 (2002): 32.

42. Smith, 98. Emphasis in the original.

43. I bid., 101. For an excellent anatomy of the moveto "nationalize" debate within Canadian context, see Mary-Jo Nadeau, "Who Is Canadian N ow? Feminism and the Politics of Nation after September 11," Atlantis 27 (2002): 14-24; and Nadeau, "Towards 'A Peaceful Solution': NAC and the Politics of Engagement," Canadian Woman Studies 22 (2003) : 48-55.

44. Smith, 104. Emphasis in the original.

45. Gary Kinsman, Dieter K. Buse, and M ercedes Steedman, eds., Whose N ational Security? Canadian State Surveillance and the Creation of Enemies (Toronto: Between the Lines, 2000), 281.

46. For a discussion of the limits of civil liberties responses, see Nadeau, "Who Is Canadian Now?" 16-18.

47. For a critique of Canadian sovereigntist perspectives, see the article by Nandita Sharma forthcoming in Canadian Dimension. Prior contributions to this debate may be viewed online: $<$ www.canadiandimension.mb.ca>.

48. Kinsman, Buse, and Steedman; Zuhair Kashmeri, The Gulf Within: Canadian Arabs, Racism, and the Gulf War (Toronto: J. Lorimer, 1991).

49. For an exception, see historian Allan Levine, "Return of the Red Scare," Globe and M ail (Toronto), 2 January 2003. There has also been limited public discussion of the internment of Japanese-Canadians during World War II. For a superb discussion of memory in relation to this historical event, see M ona Oikawa, "Cartographies of Violence: W omen, M emory and the Subject(s) of 'Internment,'" in Race, Space, and the Law: U nmappinga W hiteSettler Society, ed. ShereneH. Razack (Toronto: Between the Lines, 2002).

50. Franca Iacovetta, "M aking Model Citizens: Gender, Corrupted Democracy, and Immigrant and Refugee Reception W ork in Cold War Canada," in Kinsman, Buse and Steedman; Allan Thompson, "Security Memo Angers Groups," Toronto Star, 19 N ovember 2001.

51. Quiroz-Martinez, 32.

52. Ibid., 31. On non-citizen barriers to work in Canada, seeKirk Makin, "Ruling Favours Citizens' Rights," Globe and Mail (Toronto), $9 \mathrm{M}$ arch 2002.

53. Steve Early, "Why US Unions Turning against the War," Boston Globe, 1 March 2003.
54. Oral presentation by Hassan Yusef at Toronto forum organized by STATU S campaign, December 2001.

55. Campbell Clark, "Alarm Sounded over Border Control," Globe and M ail (Toronto), 9 April 2003.

56. Jane Bai and Eric Tang, "The War at Home," Colorlines 5 (2002): 29.

57. Campbell Clark, "PM Shrugs off Immigrants' Travel Trouble," Globe and Mail (Toronto), 6 N ovember 2001. In protest, several organization, including the Canadian Arab Federation, Canadian Council for Refugees, and the Ontario Council of AgenciesServing Immigrants, wrote an open letter to Jean Chretien, 7 N ovember 2002.

58. Estanislao Oziewicz, "Man Held 7 Months, Sent Home with NoID,"Globeand M ail (Toronto), 17 April 2002; Chisun Lee, "INSD etaineeH its, USStrikes Back: Canadian AttemptsFree dom on Habeas Suit but Gets Charged," Village Voice, 5 February 2002.

59. Klein, 10.

60. Ibid. See also N aomi Klein, "The Legacy of Austerity? A Really 'Great' Border," Globe and Mail (Toronto), 12 December 2001.

61. Lawrence M artin, "WeDidn't M ess up, They Did," Globeand M ail (Toronto), 18December 2001.

62. "Ontario Promises 'Humane' Detention Space," Globe and M ail (Toronto), 4 January 2002; Carolyn Zwarenstein, "O ur Human Chicken Coop," Eye, 13 December 2001.

63. Bai and Tang, 29. Of course, detention of immigrants was a serious issue well prior to September 11 . For one account, see M ichael Welch, Detained: Immigration Laws and the Expanding I.N.S. Jail Complex, (Philadelphia: Temple University Press, 2002). For discussion of the "prison industrial complex," see Angela Y. Davis and Cassandra Shaylor, "Race, Gender and the Prison Industrial Complex: California and Beyond," Meridians: Feminism, Race, Transnationalism 2 (2001): 1- 15.

64. Bai and Tang.

65. Honig, 82.

66. Ibid.

67. For an account of the impact of the Gulf War on Arab-American community formation, see M ervat F. Hatem, "The Invis ible Half: Arab American Hybridity and Feminist Discourses in the 1990s," in Talking Visions: M ulticultural Feminism in a Transnational Age, ed. Ella Shohat (New York: MIT Press, 1998).

68. Balibar, 42.

69. Anthony Richmond, Global Apartheid: Refugees, Racism, and the N ew W orld Order (Toronto: Oxford, 1994).

Cynthia Wright, an academic and activist, has taught women's studies at the U niversity of Toronto and Trent U niversity. Shehasalong-timeinterestin immigrant rightsmovements and is active in working for status for undocumented people in Canada. 